\title{
Advances in Joining and Welding Technologies for Automotive and Electronic Applications
}

\author{
Ashok K Srivastava ${ }^{1, *}$, Ashutosh Sharma ${ }^{2}$ \\ ${ }^{1}$ Department of Metallurgical and Materials Engineering, SOE, OP Jindal University, Raigarh (C.G.), India \\ ${ }^{2}$ Department of Materials Science and Engineering, University of Seoul, Seoul, Republic of Korea \\ *Corresponding author: ashok.srivastava@opju.ac.in
}

\begin{abstract}
The joining of various parts in engineering applications such as automotive components, aircrafts, medical implants, sensor devices, interconnections etc., are a great concern nowadays. Various types of low melting point fillers, braze and alloys have been also developed but problem of crack generation and failures are not satisfactorily treated. This paper reviews some of the developments in traditional and modern joining techniques in automotive joining and welding. Currently, joining of composites is attracting researchers for weight reduction and economy. There are many practical techniques for joining metals and ceramics to themselves and to dissimilar materials. An overview of various processes of joining metal-metal, ceramic-metal and composites, factors affecting joining and approaches used to improve the brazed joint structures are presented here. In addition, new modifications in welding and brazing processes are outlined for further directions.
\end{abstract}

Keywords: brazing, soldering, welding, steel, metal, filler, automotive

Cite This Article: Ashok K Srivastava, and Ashutosh Sharma, “Advances in Joining and Welding Technologies for Automotive and Electronic Applications.” American Journal of Materials Engineering and Technology, vol. 5, no. 1 (2017): 7-13. doi: 10.12691/materials-5-1-2.

\section{Introduction}

Metal industries are always in demand for various methods to join different parts of a component in electronic and automotive devices. In general, the joining methods can be temporary or permanent depending upon the requirement and specifications of the part [1]. In terms of metallurgy, joining is a special kind of bonding technique that produces a rigid joint between the different parts to be joined. A metallurgical bond so formed is difficult to get separated by ordinary means. Two different parts are joined together to form a single entity. The American Welding Society (AWS) defines the joining process into three major classes: welding, adhesive bonding, and mechanical fastening [2]. The mechanical methods are very traditional and historic. They use different parts like rivets, screws, bolts for tightening, while permanent bonding can only be achieved by welding in a broad view. There are various types of welding methods available in literature, for example, arc and gas welding, brazing and soldering [1]. Apart from metal to metals or non-metals in present scenario, different techniques for joining ceramics to metals or nonmetals are possible and have successfully gained popularity in ceramic industries [3]. In a broad sense we have various types of bonding processes, such as mechanical joining, adhesive welding, friction welding [4], high energy beam welding [5], microwave joining, ultrasonic welding [6], explosive welding [7], reactive joining, combustive joining [8], field assisted joining [9], brazing, diffusion bonding [10], transient liquid phase (TLP) bonding and partial TLP bonding etc. [11].

\section{Classification of Joining Processes}

As discussed, the joining processes involves mainly welding, brazing and soldering process. However, each process is different from each other and various modifications exist depending upon the temperature and joining conditions. Various types of welding processes according to their source of heat application have been shown in Figure 1.

\subsection{Welding}

Welding is a process in which metal parts are bonded together using a higher temperatures. During welding, the workpieces are melted down at the joint and an additional filler metal or welding electrode is also supplied in the molten pool which aids in joining that solidifies and makes a rigid joint. In this process, both similar and dissimilar metals can be joined easily. The weld structure is formed as a result of fusion of the parts involving diffusion of materials as compared to traditional mechanical fastening. There are various kinds of developments in welding like use of current to generate a high temperatures. The welded joint have higher strength and has been applied to develop materials and alloys having high strength, low alloy steels composites etc. $[2,13]$. The various welding processes according to the source of heat, can be classified as follows [14]. 


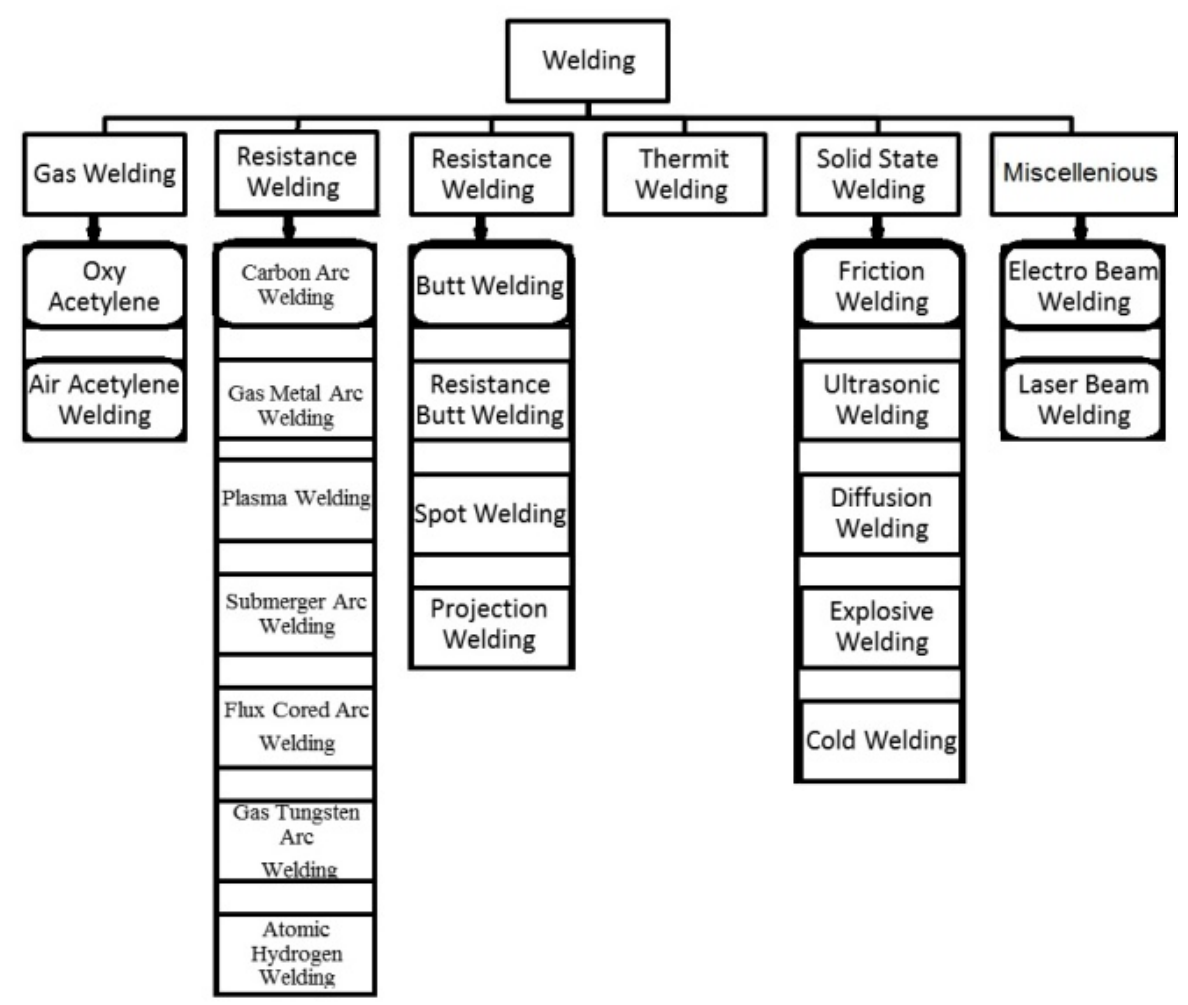

Figure 1. Various types of welding processes according to their source of heat application

\subsubsection{Gas Welding}

The gas welding involves a kind of gas which is a mixture of the oxygen or air with acetylene, for example in the oxygen-acetylene welding. Various other gasses are also found useful in place of acetylene as given in Table 1, with their various temperature ranges [2]. Generally, oxy-fuel welding (OFW) is used to designate the gas welding that utilizes a fuel gas with oxygen to generate a flame. Acetylene is the most important gas fuel in welding. These oxy-fuel combination can also be used for the gas cutting of metals together in conjunction with welding. Other variations of oxy-fuel welding include combination of acetylene and air. However, in air, the thermal efficiency and welding speed becomes poor and joint is distorted. Acetylene welding has been applied to the various sheet metal fabrications in automotive industries and repair of parts.

Table 1. Various fuel gasses in welding and their temperature ranges

\begin{tabular}{|l|c|}
\hline Fuel gases & Max. Temp $\left({ }^{\circ} \mathrm{C}\right)$ \\
\hline Acetylene & 3300 \\
\hline Mythylacetylene-propadiene & 2900 \\
\hline Propylene & 2860 \\
\hline Propane & 2780 \\
\hline Methane & 2740 \\
\hline Hydrogen & 2870 \\
\hline
\end{tabular}

\subsubsection{Arc Welding}

Arc welding is being frequently used in industries due to its simple, economical, versatile and broad spectrum applications. In arc welding, electric arc is used as a heat source from melting. The arc is generated between electrode filler and the part to be joined. The filler rod consumable rod or wire, or non-consumable tungsten wire. A shielding gas is also used to prevent oxidation of molten metal during welding. Argon, carbon dioxide, helium or various gas mixtures have been used. Arc welding finds application in various indispensable construction of steel frames for buildings, shipping constructions, galvanized steels for car bodies, motor manufacture, and power plants industries. Arc welding is further divided into gas metal arc welding (GMAW) including metal active gas (MAG) or metal inert gas (MIG) welding, submerged arc welding, flux cored arc welding, plasma welding etc. Recent developments include, cold arc welding or cold metal transfer (CMT) have attracted as an alternative to controlled energy transfer in welding [15].

Submerged arc welding (SAW) is a variation of arc welding process where the arc is produced beneath the granular flux and other compounds. The process requires a continuously fed welding filler to the part $[1,15]$. SAW is beneficial in the sense that it can produce high quality, smooth and uniform weld joint without any smoke and flash in the process. Nearly all ferrous metals can be joined with exceptional quality, such as alloy and stainless steels for automotive. The only disadvantage of this process compared to other arc welding techniques is the unsuitability to positional welding. Only flat substrate welding with an inclination up to $15^{\circ}$ from the part can be tried [16].

Flux-cored arc welding (FCAW) is similar variation of GMAW where flux is used for protection and is contained within the core of a tubular electrode instead of applying over the electrode. Flux core provides a more stable arc, improved weld joint and better, and a better mechanical properties $[1,17,18]$. Although FCAW can be configured in some positional welding yet the weld slag is difficult to control sometimes [17]. FCAW process may or may not require the gas shielding. 
Gas tungsten arc welding (GTAW) is a completely similar process to MIG or MAG process where a non-consumable electrode is used in conjunction with $\mathrm{Ar}$ or He gas for shielding [16]. Tungsten electrode is non-consumable, therefore, a stable arc gap should be maintained at a constant current supply. Tungsten electrodes ae sometimes alloyed with $1 \% \mathrm{Zr}$ or Th to improve the resistance towards contamination and maintaining stable arc $[16,17]$. Tungsten inert gas (TIG) or GTAW has better promising capabilities in the welding market due to its suitability to automation, use for high-quality joints, welding thin sections of dissimilar metals etc. [1].

In the case of plasma arc welding (PAW), a mixture of gasses are heated to a very high temperature to ionize and conduct electricity. PAW employs an inert gas and nonconsumable electrode to generate the arc. The arc can be used in two forms, such as transferred and non-transferred arcs. To control the energy output the arc can be used on the site of part or from the nozzle. For instance, the transferred arc is produced between the part and the electrode. The non-transferred arc is produced between the part and filler nozzle. Mostly, the transferred arc process is used for the welding applications.

\subsubsection{Resistance Welding}

Resistance welding (RW) is a non-fusion welding process which involves the heating of metals through the electrical resistance of the part against the current supply. Application of pressure to the part and the localized resistance heating at the weld results in the joining. RW is used for joining various metals and alloys, motor parts, fuel tanks, radiators, gas and oil pipeline parts, railway tracks, turbine parts, etc. The principle of the RW is the production of heat energy when electricity is passed across a smaller cross section of contacting metal parts. If I is the current flow for the time $\mathrm{t}$, the heat $\mathrm{H}$ generated can be given by:

$$
\mathrm{H}=\mathrm{I}^{2} \times \mathrm{R} \times \mathrm{t} .
$$

At a sufficiently high temperature, enough pressure is applied at the joint to produce a rigid bonding. The amount of heat generated further depends upon the current, time, pressure, as well as on the thickness of the part. Various variation of RW are spot welding, seam welding, projection welding, and flash welding $[16,19]$.

In spot welding, the parts to be joined in overlapped position and two filler rods are placed on both sides of the part. Spot welding is popular in automotive industry for joining various separate points on the on the part [16]. Seam welding as similar to spot welding is the continuous welding of sheets placed one into another [18]. Flash welding involves producing an arc between two ends of a rod, tube or sheet by resistance heating and applying the pressure to form the weld [16]. The butt welding is similar to flash welding, except the pressure and current are applied simultaneously. In flash welding, the electric current is produced after the application of pressure $[17,19]$.

A more variation of spot resistance welding is projection welding where the welding is done only at the projection sites in the plates or sheets via applying pressure and current. Projection welding is promising for mass production and where a series of spot welding is needed in a given area [20]. Generally, projection welding is used for welding steel brackets, clamping and encapsulation of parts.

\subsubsection{Thermite Welding}

Thermite material is used for melting the parts and pouring the molten metal between the two parts to be joined. It is a kind of exothermic process and do not need any current source. The joining is achieved using a thermite reaction between a reducing metal and metal oxide, for example, $\mathrm{Al}$ and a $\mathrm{Fe}_{2} \mathrm{O}_{3}$. As a result, $\mathrm{Al}_{2} \mathrm{O}_{3}$ and a molten $\mathrm{Fe}$ are produced. Due to the explosive nature of this process, this is used in special conditions like situations like butt joining of railway tracks, thick parts of cast iron and steels bars; or where there is no other process is applicable for welding [1,4,5,6,7,8,21-26,29]. This process is also used dissimilar metals joining like $\mathrm{Cu}$ to steel or $\mathrm{Cu}$ to $\mathrm{Al}$ welding in electricity transportation. Suban and his co-workers have used this method to join steel surface and $\mathrm{Cu}$ according to the reaction [27]:

$$
3 \mathrm{CuO}+2 \mathrm{Al} \rightarrow 3 \mathrm{Cu}+\mathrm{Al}_{2} \mathrm{O}_{3}+\text { Heat. }
$$

Another method has been used by Rejdak to join Al to other metals [28]:

$$
\begin{gathered}
3 \mathrm{SnO}_{2}+4 \mathrm{Al}(\mathrm{s}) \rightarrow 2 \mathrm{Al}_{2} \mathrm{O}_{3}+3 \mathrm{Sn}+\text { Heat } \\
3 \mathrm{SnO}+2 \mathrm{Al} \rightarrow \mathrm{Al}_{2} \mathrm{O}_{3}+3 \mathrm{Sn}+\text { Heat. }
\end{gathered}
$$

\subsubsection{Solid State Welding}

Solid state welding includes friction welding, ultrasonic welding, diffusion and cold welding, explosive welding, forge welding etc. In friction welding, the source of heat is the frictional force between the two contact surfaces with pressure to the extent the interface becomes soften [30]. The frictional heat produced at the interface contacts is used to weld the parts. The application includes the automotive bodies, high-speed tool steels, and twisted drill.

Another type of solid state welding is cold welding process where particles are bombarded over the substrates under pressure to produce deformation and joining. It requires no fusion and energy supply at interfaces. It is faster than most of the welding processes [31,32]. The cold welding is an attractive process for nanostructures or in mechanical alloying to create various nanostructures such as carbon nanotubes and composites, metal/ceramic nanowires and nanoparticles [31,32,33].

Diffusion welding is a joining process which involves high temperature, pressure and time for diffusion without any use of filler metal and little deformation. Application of pressure at a given temperature is essential for causing localized creep diffusion. Sometimes an inter-coating layer is used to enhance the diffusion bonding [34].

Explosive welding is done as a result of tremendous power produced by detonating explosives. The clean contact parts are pressed down at million $\mathrm{kg} / \mathrm{cm} 2$ by the explosive. Dissimilar metals like $\mathrm{Al}$ or steel to $\mathrm{Ti}$ is feasible by this process [35]. Extremely brittle metals cannot be used by this process. Explosive welding is most suited for cladding applications.

In ultrasonic welding, the heat source is a high-frequency vibrator as the contacting surfaces are held under pressure. Yousefpour and his co-workers have categorized ultrasonic welding as a type of frictional fusion welding which produce heat under pressure [36,37]. Troughton et al described ultrasonic welding as one of the important 
method for joining thermoplastics [38]. The joining can be achieved within less than a second.

\subsubsection{Miscellaneous Welding Processes}

Electro slag welding (ESW) is a process where the parts to be joined are melted down using a molten slag which shields the weld pool. ESW offers good productivity and quality in heavy structural and pressure vessel fabrications. For a stable welding, the molten slag temperature should be fixed. ESW process is entirely continuous and productive, defect free, time-saving for the filler metal and flux.

Electron beam welding (EBW) involves heat source obtained by the impact of a high-velocity high-density electron beam onto the part. The kinetic energy of the electrons is transformed to heat energy which vaporizes and melts down the part. Electron beam welders focus the electron beam very precisely to deflect the beam up to 10 $\mathrm{kHz}$. Recent developments in electron beam machines can make it to go up to $200 \mathrm{kHz}$ [39].

Similar to electron beam, in the laser welding method, the metals are joined by targeting a laser beam on the part under high velocity. The application of laser welding has received a great attention in past few decades due to its higher productivity, higher speeds, and greater penetration as compared to other welding methods with an exception of electron beam welding [40]. The most applications are in the locomotives, transmission gears, clutch, pipeline welding, ship building, nuclear plant etc.

\section{Joining of Ceramics to Metals}

Generally, joining dissimilar materials is not feasible in a normal sense due to their mismatch in material properties [20]. Various types of metal-ceramic joining processes has been shown in Figure 2. Ceramics are not easy to wet by metals due to their strong covalent bonding. Therefore, a reaction layer is applied over the ceramics to wet the contact surface and bond the metal part during melting. Though due to the difference of their thermal expansion coefficients and elastic moduli, distortion and residual stresses are generated after bonding which is deleterious to the mechanical performance of the joint and may rupture eventually [40,41,42,43]. Dissimilar metal joining has enabled researchers to join ceramics and to produce a number of hybrid devices, mechanical sensors, cutting tools, weather monitoring devices [20,44,45,46].

Though the various applications of ceramic to metal joining is in the beginning stage, notable $\mathrm{ZrO}_{2} / \mathrm{Al}$ and $\mathrm{ZrO}_{2} / \mathrm{Ti}$ joints are available in literature [20,48,49,50]. Various kinds of organic adhesives used for the ceramic-metal joining are given in Table 2.

Table 2. Organic adhesive used in ceramics/metal joining [20,50]

\begin{tabular}{|l|c|c|}
\hline Adhesive & Setting & Working Temp. $\left({ }^{\circ} \mathrm{C}\right)$ \\
\hline Epoxy & hot & $170-220$ \\
\hline Polyurethane & Hot + Cold & $120-180$ \\
\hline Silicon & Cold & $180-220$ \\
\hline Cyanoacrylate & Cold & $150-250$ \\
\hline Elastomer & Hot & $90-110$ \\
\hline
\end{tabular}

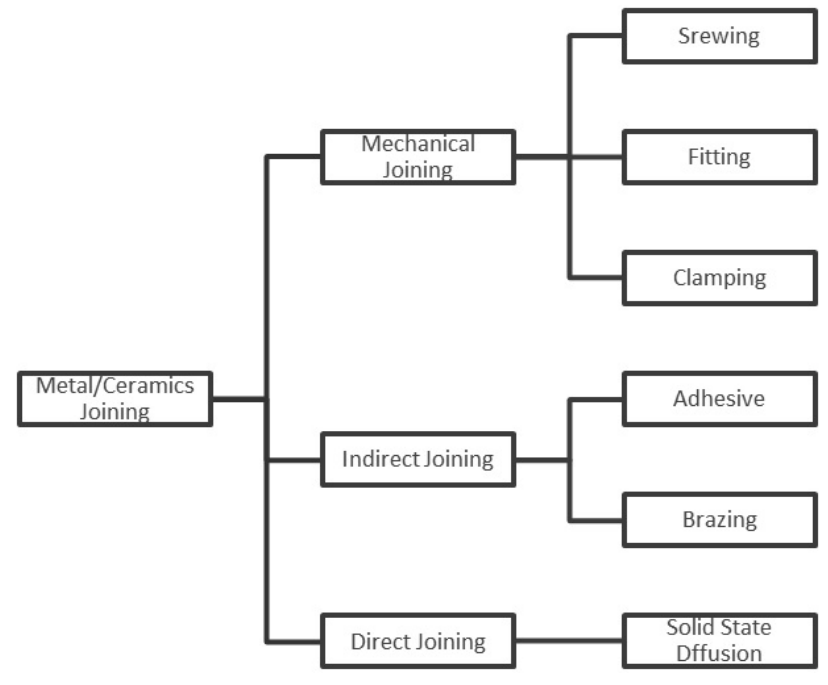

Figure 2. Various types of metal-ceramic joining processes

\section{Brazing}

Compared to welding, brazing is a joining processes which occurs at a lower temperature up to $425^{\circ} \mathrm{C}$ and the melting temperature is lower than that of the metal parts. Brazing can also be used for the joining of dissimilar materials. A good joint depends upon the various factors like filler material, processing conditions, wetting of base metal by the filler metal $[16,17]$. In short various factors that should be kept in mind are as follows:

a) Proper joint design.

b) Proper cleaning and surface preparation of the parts.

c) Gap clearance, smoothness, etc.

d) Type of filler metal.

e) Brazing temperature and time, environment, heating rates etc.

Compared to welding, brazing need less amount of energy and the strength of brazed joint is poor. Therefore, the brazing is not highly utilized in repairing aircraft structures [17]. There are few important brazing techniques are available at low temperature like dip brazing, induction brazing, torch brazing, resistance brazing, furnace brazing, and laser brazing [53,54,55,56]. Oxygen and oxyacetylene torch brazing involves use of brazing torch flame to melt the filler at the joint. A reducing flame is used generally to prevent the oxidation. Furnace brazing involves the metal parts to braze in the furnace in neutral or reducing atmosphere and cooled down and removed. Another induction brazing uses electrical resistance heating of the part at high frequency for heat generation. Similarly, the resistance welding uses direct electrical connection rather than electromagnetic induction process. The equipment for resistance welding and brazing are generally the same. There are various other brazing methods depending upon the type of heat source as in case of welding technology like infra-red brazing, dip brazing in molten pool, arc brazing, laser brazing etc.

\section{Factors Affecting Brazed Joint}

There are various factors that affect the quality of a brazed joint. Some of the critical ones are intermetallic 
compound generation, wetting, temperature, type of filler, and process conditions etc. For example, in titanium brazing to steel, the thickness of intermetallic depends upon the temperature strongly. The shear thickness also increases when the intermetallic compound thickness is smaller [59]. Poor wetting properties of ceramic are also a critical factor. Active metal brazing have been devised for ceramic to metal brazing by using active elements as wetting agents for ceramic surfaces [60]. A superior wetting property of galvanized steel is a consequence of lower wetting angle over bare steel [61].

Brazing temperature also influences the bond strength and the atmospheric corrosion rates of brazed joints due to the difference in intermetallic compound distribution at a particular brazing condition [62]. Active brazing of $\mathrm{Al}_{2} \mathrm{O}_{3}$ to $\mathrm{Cu}$ with $\mathrm{Ag}-\mathrm{Cu}-\mathrm{Zr}-\mathrm{Sn}$ filler at lower temperature results in higher bond strength compared to that at higher brazing temperature $[63,64]$. Different types of fillers are available for brazing also show different results. Like, Cu-based filler at $1000^{\circ} \mathrm{C}$ produces higher shear strength as compared to $\mathrm{Ag}$ fillers brazed at $850^{\circ} \mathrm{C}$. This may be ascribed to the fact that $\mathrm{Cu}$ filler has a higher strength as compared to Ag based filler [65,66]. Various composite fillers also are being researched for $\mathrm{Al}$ alloys like low melting point Al-Si-Cu-Ni-RE filler as compared to eutectic Al-12Si filler [67]. Carbon fibers added to Ag based filler (63Ag-34Cu-2Ti-1Sn) showed an increment in joint strength by $30 \%$ between steel and $\mathrm{Al} 2 \mathrm{O} 3$ [68,69]. Brazing atmosphere is also critical for the final joint performance by preventing additional oxidation products and gaseous impurities. $\mathrm{Ni}, \mathrm{Fe}$ and Co-based alloys containing $37-82 \% \mathrm{Au}$ is used where high corrosion and oxidation resistance is required [70,71]. Application of $\mathrm{TiH}_{2}$ is found useful as it prevents the usual metallising, plating steps [72,73]. The shear strength of the brazed joint also depends on the design like lap width. The shear strength has been found to increase as the lap width falls in case of $\mathrm{Ti}$ to low carbon steel joining with Ag filler in vacuum [59]. People have also tried a transient liquid phase bonding (TLP) where the increase in frequency from 0 to $400 \mathrm{~Hz}$ and amplitude of 20 micrometer of mechanical vibrations increases the bonding strength [73]. Moreover, the vacuum brazing of Ti-Al alloy to 40Cr steel using Ag-Cu-Zn filler metal shows that the joint strength depends on the brazing time which further depend upon the joint microstructure to a large extent [74].

\section{Soldering}

Soldering is also a type of brazing that works at low temperatures lower than $450^{\circ} \mathrm{C}$. The soft specimens are generally joined using solders like joints between $\mathrm{Cu}, \mathrm{Cu}-$ $\mathrm{Zn}, \mathrm{Sn}, \mathrm{Cu}-\mathrm{Sn}$, etc. to join electronic components. Various types of solders are available nowadays like $\mathrm{Sn}-\mathrm{Ag}, \mathrm{Sn}-\mathrm{Cu}$, $\mathrm{Sn}-\mathrm{Ag}-\mathrm{Cu}$, including the composites which are mostly lead-free. The conventional toxic lead-tin solder is now avoided due to the European directives like WEEE and RoHS $[2,13]$. The contact surfaces are not melted during soldering but are wetted by the solder completely. The most popular alloy is $\mathrm{Sn}-3.0 \mathrm{Ag}-0.5 \mathrm{Cu}$ which matches the conventional $\mathrm{Pb}-\mathrm{Sn}$ solder although there is no perfect replacement so far. The lead-free solders provide better strength to the joint but there is a problem of $\mathrm{Cu}_{6} \mathrm{Sn}_{5}$, $\mathrm{Cu}_{3} \mathrm{Sn}, \mathrm{Ag}_{3} \mathrm{Sn}$ etc. intermetallic compounds formation which are undesirable for a robust joint. Modern research focuses on distributing these large intermetallic compounds by various composite and mechanical extrusions and rolling methods and still more research is needed to bring them in the market completely as a lead-free alternative.

\section{Conclusions}

There are various conclusions that can be sought from the present review on welding brazing and soldering technologies. Micro joining methods are very important for joining of various metals-metals, metals-ceramic, metals-nonmetals/composites in modern science and technology. All these process differ from one another in source of heat and have specific advantages and disadvantages based on application and process conditions. Welding is very promising in automotive and aerospace industries for steel components. Like in galvanized steel welding by arc and laser are most popular due to their productivity. GMAW has a better control and higher productivity and can evolve as a substitute for various joining applications as compared to expensive laser and electron beam welding. Thermite welding is generally used for special cases like railway tracks where no other process is applicable. Brazing is also a good joining technique for various metals and non-metals and the lower limit is $450^{\circ} \mathrm{C}$. However, it depends upon the various factors like temperature, formation of intermetallic compounds, process conditions etc. Wetting is also an important factor in micro joining. Ceramic-metal joining is accomplished using active element coating layers on the ceramic metal before bonding at high temperature and application of pressure. Ceramic-metal joining has applications in dental implants for joining $\mathrm{Ti}$ and $\mathrm{ZrO}_{2}$ in particular. Soldering has a great application as an electronic joining. Conventional solders are not allowed and lead-free solders are developed to match the $\mathrm{Pb}-\mathrm{Sn}$ solder. More research is needed to develop micro joining materials and this review can be a guideline for the development of various joining materials.

\section{References}

[1] Mauldin, T. C. and Kessler, M. R., "Self-healing polymers and composites,” Int. Mater. Rev., 55, 317-346, 2010.

[2] Kah, P. and Martikainen, J., "Current Trends in Welding Processes and Materials: Improve in Effectiveness," Reviews on Advanced Materials Science, 30, 189-200, 2012.

[3] Dhakal, H.N, "Lecture Notes on Welding, Mechanical and Marine Engineering” School of Engineering, University of Plymouth, England U.K, 2008.

[4] Peteves, S.D.”Joining Structure Ceramics in Designing Interfaces for Technological Applications”, Elsevier Applied Science, London, UK, 1989.

[5] Fernie, J.A., Threadgill, P.L. and Watson, M.N. "Progress in Joining of Advanced Materials. Welding and Material Fabrication”, 59(4), 179-184, 1991.

[6] Maloletov, M.P. "Theoretical Fundamentals and Technology of Electron Beam Welding Ceramics to Metals.” Welding International, 64(3), 237-239, 1995. 
[7] Matsuoka, S "Ultrasonic Welding of Ceramics/Metals Using Inserts” Journal of Materials Processing Technology, 75(2), 259-265, 1998.

[8] Hokamoto, K., Fujita, M. Shimokawa and Okugawa, H. “A New Method for Explosive Welding of $\mathrm{AI} / \mathrm{ZrO}_{2}$ Joint Using Regulated Underwater Shock Wave," Journal of Materials Processing Technology,85(1), 175-179, 1999.

[9] Miyamoto, Y., Nakamoto, T., Koizumi and M., Yamada, O. "Ceramic to Metal Welding by a Pressurized Combustion Reaction,” Journal of Material Research (1), 7-9, 1986.

[10] Meng, Q.S. and Xue, J. "Joining Mechanism of Field-Assisted Bonding of Electrolytes to Metals "Transactions of Nonferrous Metals Society of China,13(5), 1092-1095, 2003.

[11] Novikov, V.G. "Diffusion Bonding Dissimilar Materials in Aerospace Technology,” Welding International, 65(6), 477-478, 1995.

[12] Zhang, Y., Feng, D., He, Z.Y. and Chen, X.C. "Progress in Joining Ceramics to Metals" Journal of Iron and Steel Research International,13(2), 01-05, 2006.

[13] Leinfelder, K.F. and Lemons, J.E,”Clinical Restorative Materials and Techniques": Lea and Fibiger, Philadelphia, 139-157, 1988.

[14] Anusavice, K.J., Shen, C. and Rawls, H.R. "Phillips Science of Dental Materials,” 12th edition, Saunders, Philadelphia, 608-618, 2003.

[15] Aggeliki, K. “Classification of Welding Processes”, eds, L. Stonecypher, May 2011. http://www.brighthubengineering.com.

[16] History of Welding, in: "Introduction to Welding and Oxyfuel" p.1-12. Available from www. Aws.org.

[17] Mishra, R.S. and Ma, Z. "Friction Stir Welding and Processing”. Materials Science and Engineering R, 50, 1-78, 2005.

[18] Koshiishi, F. "Welding Duplex Stainless Steel”, Kobelco Welding Today, 19, 1-10, 2016.

[19] Kim, J.H. and Yoo, Y.C. "Bonding of Alumina to Metals with Ag$\mathrm{Cu}-Z r$ Brazing Alloy” Journal of Materials Science Letters, 16, 1212-1215, 1997.

[20] Nascimento, R.M. do, Martinelli, A.E. and Buschinelli, A.J.A. "Review Article: Recent Advances in Metal-Ceramic Brazing.Ceramica,” 49, 178-198, 2003.

[21] Abnar, B., Ghafouri, P.S. and Aghajani, H. "Thermite Welding of Aluminum Conductor by Addition of Copper," Proceedings of Iran Int. Aluminium Conference (IIAC2012), University of Tabriz, Iran, 2012.

[22] Lonsdale, C. P., and M. Engineer. "Thermite rail welding: history, process developments, current practices and outlook for the 21st century." Proc. of the AREMA 1999 Annual Conf. Chicago, IL. 1999.

[23] Wang, Y., Hu, Z., Shi, Y. and Wang X. "Experimental Study on Mechanical Properties of Rail Thermit Welding Joints at Low Temperature,” Proceedings of 19th International Offshore and Polar Engineering Conference, Osaka, Japan, 2009.

[24] Redkin, K.V., Garcia, C.I., Deardo, A.J., Gutscher, D. and Kalay, S."Microstructure Analysis of Thermite Welds," ASME 2010 Joint Rail Conference, JRC 2010, Code 81896, Vol. 1, 149-156, 2010.

[25] Rajanna, S., Shivanand, H.K., Akash Deep, B.N. "Improvement in Mechanical Behavior of Improvement in Mechanical Behavior of Rail Steel.”International Journal of Mechanical, Aerospace, Industrial, Mechatronic and Manufacturing Engineering, 3(12), 1545-1549, 2009.

[26] Davies, A.C.”The Science and Practice of Welding,"Vol.1, Welding Science and Technology, 10th edition, Cambridge University Press, 42-43, 2003.

[27] Suban, M., Bozic, S., Zajec, A., Cvelbar, R. and Bundara, B. "Crack analysis in Thermite Welding of Cathodic Protection" Nuclear Engineering and Design, 246, 123-127, 2012.

[28] Rejdak, M.F. "Method for Welding Aluminum Article to Another Metal Article”, US Patent No. 2870498, 1959.

[29] Messler, Jr., R.W. “Joining of Materials and Structures,” Elsevier Butterworth-Heinemann, 2004, 611-679, 2004.

[30] Raghavendra, D.R., Sethuram, Dr. and Raghupathy, V.P. "Comparison of Friction Welding Technologies," International Journal of Innovative Science, Engineering \& Technology, 2 (12), 2015.

[31] Cha, S.H., Park, Y. and Cho, C. "Cold Welding of Gold Nanoparticles on Mica Substrate: Self-Adjustment and Enhanced Diffusion”, Scientific Reports 6, 32951, 2016.
[32] Lu, Y. Huang, J.Y., Wang, C., Sun, S. and Lou, L. "Cold Welding of Ultrathin Gold Nanowires” Nature Nanotechnology, 5, 218-224, 2010.

[33] Kim, S.J. and Jang, D.J. “Laser-Induced Nanowelding of Gold Nanoparticles.” Applied Physics Letters, 86, 033112, 2005.

[34] Kazakov, N.F. "Diffusion Bonding of Materials", Pergamonn, Elsevier., 2013.

[35] Andreas, B. and Peguiron, D.A. "Explosive Joining of Precious Metals.”Gold Bulletin, 31(3), 93-98, 1998.

[36] Yousefpour, A., Hojjati, M. and Immarigeon, J.P. "Fusion Bonding/Welding of Thermoplastic Composites.”Journal of Thermoplastic Composite Materials, 17, 303-34, 2004.

[37] Rashli, R., Bakar, E.A., Kamaruddin, S. and Othman, A.R. (2013) A Review of Ultrasonic Welding of Thermoplastic Composites. Caspian Journal of Applied Sciences Research, 2(3), 01-16, 2013.

[38] Troughton, M.J. "Handbook of Plastic Joining: A Practical Guide", 2nd edition, William Andrew Inc., New York, 2008.

[39] Schubert, G. "Electron Beam Welding-Process, Applications and Equipment." Proceedings of the IIW International Conference on Advances in Welding and Allied Technologies. 2009.

[40] Nascimento, R.M.”MetalizaçãoMecânica de Al2O3 Para Brasagem Metal/Cerâmica”. D. Eng. Thesis, UFSC, Brasil (in Portuguese), 2001.

[41] Paiva, O.C. and Barbosa, M.A.’Brazing Parameters Determine the Degradation and Mechanical Behaviour of Alumina/Titanium Brazed Joints.” Journal of Materials Science, 35, 1165-1175.

[42] Howe, J.M. "Bonding Structure and Properties of Metal/Ceramic Interfaces, Part 2: Interfacial” Fracture Behavior and Property Measurement. International Materials Review, 38(5), 257-271, 1993.

[43] Watkins, R.D. Ceramics and Glasses, ASM Handbook, Vol. 4, 478, 1991.

[44] Martinelli, A.E. "Diffusion Bonding of Silicon Carbide and Silicon Nitride to Molybdenum.” PhD Thesis, McGill University, Montreal, Canada, 1996.

[45] Srivastava, M. and Sherpa, B.B. "Review of the High Vacuum Metal-Metal and Metal-Ceramic Brazing Process.” International Journal of Engineering Research and Applications, 43-46. 2014.

[46] Suganuma, K. "Reliability Factors in Ceramic/Metal Joining." Proceedings of Materials Research Society Symposium, 314, 51, 1993.

[47] Klomp, J.T. and De, G. "With Strong Metal/Ceramic Joints." Materials \& Manufacturing Processes, 8(2), 129-157, 1993.

[48] Sharma, A., Kee, S.H., Jung, F., Heo, Y. and Jung, J.P. "Compressive Strength Evaluation in Brazed $\mathrm{ZrO} 2 / \mathrm{Ti6Al4V}$ Joints using Finite Element Analysis.”Journal of Materials Engineering and Performance, 25, 1722-1728, 2016.

[49] Akselsen, O.M.“ Diffusion Bonding of Ceramics.” Journal of Materials Science, 27, 1989-2000. 1992.

[50] Boretius, Manfred, Erich Lugscheider, and Wolfgang Tillmann. Fügen von Hochleistungskeramik: Verfahren, Auslegung, Prüfung, Anwendung. VDI-Verlag, 1995.

[51] Shepeleva, L., Medres, B., Kaplan, W.D., Bamberger, M. and Weishiet, A."Laser Cladding of Turbine Blades.” Surface \& Coating Technology, 125, 45-48, 2000.

[52] Curicuta, V., Alexander, D.R., Liu, Y., Robertson, B.W. and Poulain, D.E. Furnace and Laser Methods of Bonding Metals to Ceramics: Interface Investigation. Materials Science and Engineering B, 68, 196-203. 2000.

[53] Induction Atmospheres, in: The Brazing Guide, Turnkey Heating Solutions, 1-10. Available from www.inductionatmospheres.com.

[54] Brazing - A Guide to Best Practice. The Indian Institute of Welding, Available from http://theiiwmumbai.8m.com/brazing4.html

[55] Sharma, A., Shin, Y.S. and Jung, J.P. "Influence of Various Additional Elements in Al Based Filler Alloys For Automotive and Brazing Industry.”Journal of Welding and Joining, 33(5), 1-8, 2015.

[56] Pahwa, R., Singh, T., Sagar, D. and Singh, G. "Feasibility of Brazing as Joining Process.” International conference on Science, Technology and Management (ICSTM 2015), YMCA, New Delhi, India, 901-971, 2015.

[57] Milhaupt, L. Knowledge Base, 'How Brazing Works? Available from

http://www.lucasmilhaupt.com/enUS/brazingfundamentals/howbr azingworks/. 
[58] Elrefaey, A. and Tillmann, W. "Interface Characteristics and Mechanical Properties of the Vacuum-Brazed Joint of TitaniumSteel having a Silver-Based Brazing Alloy.” Metallurgical and Materials Transactions A, 38(12), 2956-2962, 2007.

[59] Elrefaey, A. and Tillmann, W. "Brazing of Titanium to Steel with Different Filler Metals: Analysis and Comparison.” Journal of Materials Science, 45(16), 4332-4338., 2010.

[60] Calliari, I., Ramous, E., Brunelli, K., Dabala, M. and Favaron, P. "Characterization of Vacuum Brazed Joints for Superconducting Cavities.” Microchimica Acta 147, 141-146, 2004.

[61] Koltsov, A. Bailey, N. and Cretteur, L.J. "Wetting and Laser Brazing of Zn-Coated Steel Products by Cu-Si Filler Metal," Journal of Materials Science, 45(8), 2118-2125, 2010.

[62] Sharma, A., Lee, S.H., Ban, H.O., Shin, Y.S. and Jung, J.P. "Effect of Various Factors on the Brazed Joint Properties in Al Brazing.” Journal of Welding and Joining, 34(2), 30-35, 2016.

[63] Liu H. and Feng J. "Vacuum Brazing TiAl-Based Alloy to 40Cr Steel using Ag-Cu-Zn Filler Metal.” Journal of Materials Science Letters21, 9-10, 2002.

[64] He, Y.M., Zhang, J., Wang, X. and Sun, Y. "Effect of Brazing Temperature on Microstructure and Mechanical Properties of Si3N4/Si3N4 Joints Brazed with Ag-Cu-Ti + Mo Composite Filler” Journal of Materials Science, 46(8), 2796-2804, 2011.

[65] Elrefaey, A.A.M. and Tillmann, W. "Microstructure and Mechanical Properties of Brazed Titanium/Steel Joints.” Journal of Materials Science, 42(23), 9553-9558, 2007.

[66] Sharma, A. and Jung, J.P. “Aluminium Based Brazing Fillers For
High Temperature Electronic Packaging Applications.” Journal of the Microelectronics and Packaging Society, 22(4), 1-5, 2015.

[67] Zhang, G., Bao, Y., Jian, Y. and Zhu, H. "Microstructure and Mechanical Properties of 6063 Aluminum Alloy Brazed Joints with Al-Si-Cu-Ni-RE Filler Metal,” Journal of Materials Engineering and Performance, 20(8), 1451-1456, 2011.

[68] Ding, W.F., Xue, J.H., Chen, Z.Z., Su, H.H. and Fu, Y.C. "Brazed Joints of CBN Grains and AISI 1045 Steel with AgCuTi-TiC Mixed Powder as Filler Materials.” International Journal of Minerals, Metallurgy and Materials, 18(6), 717-724, 2011.

[69] Zhu, M. and Chung, D.D.L. "Improving the Strength of Brazed Joints to Alumina by Adding Carbon Fibers.” Journal of Materials Science32, 5321-5333, 1997.

[70] Tasker, A. M. “Gold-Containing Brazing Filler Metals. Gold Bulletin, 16(4), 111-113, 1983.

[71] Rosser, J.B. "Gold Brazing on the Concorde Airframe Hydraulic System. Gold Bulletin, 9(4), 119-122, 1976.

[72] Paiva, O.C. and Barbosa, M.A. "Production, Bonding Strength and Electrochemical Behaviour of Commercially Pure Ti/Al2O3 Brazed Joints.” Journal of Materials Science 32, 653-659, 1997.

[73] Wu, X., Li, H., Chandel, R.S., Lan, F. and Seow, H.P. "Effect of Mechanical Vibration on TLP Brazing with BNi-2 Nickel-Based Filler Metal. Journal of Materials Science Letters, 18, 1615-1617, 1999.

[74] Liu, H. and Feng J. "Vacuum Brazing TiAl-Based Alloy to $40 \mathrm{Cr}$ Steel using Ag-Cu-Zn Filler Metal.” Journal of Materials Science Letters, 21, 9-10, 2002. 